\title{
Supply chain management: an integrative review from the agency theory perspective
}

\author{
Raul Beal Partyka
Department of Operations Management,
alio Vargas's Sao Paulo School of Business Administration \\ Raul Beal Partyka
Department of Operations Management, \\ Raul Beal Partyka
Department of Operations Management,
Fundação Getulio Vargas's Sao Paulo School of Business Administration \\ (FGV EAESP), Sao Paulo, Brazil \\ (FGV EAESP), Sao Paulo, Brazil
}

\begin{abstract}
Purpose - The purpose of the article is to demonstrate how agency theory has been used to address the dynamics involved in supply chain management. It is also dedicated to suggesting an agenda for future research. Design/methodology/approach - We performed an integrative literature review, based on the process detailed by Botelho et al. (2011), with search filters. The articles were obtained from the Scopus and Web of Science databases using the keywords "supply chain" and "agency theory", with a subsequent analytical filter for "management". The search initially identified 205 articles. After two screenings, 56 articles were selected for analysis.

Findings - Despite attempts to infer the importance of research on agency theory in supply chain management, its application to the discipline is scarce. Clearly, agency theory provides valuable insights into the relationships in the supply chain. In the studies analyzed, the dynamics of performance, risk, sustainability, dyadic and inter-firm relationships, and supplier management are predominant.

Originality/value - When considering unwanted behaviors throughout the supply chain, agency theory fills the explanatory gaps for these facts. It also proves to be a useful tool to answer mainly the dilemmas of underlying theories, such as transaction cost theory, resource-based view and network theory. Rare are the studies that examine the current state of the application of agency theory in the supply chain literature in the management field.
\end{abstract}

Keywords Agency theory, Supply chain management, Relationship management, Integrative review

Paper type Literature review

\section{Introduction}

Throughout the development of scientific literature, agency theory has become one of the most influential theories in the social sciences and has been applied to various forms of relationship (Aßländer, Roloff, \& Nay1, 2016). The theory proved to be adequate to illustrate supply chain relationships and points out implications for companies, it is also capable of providing information to companies on how to implement and design supply chain relationships (Wiese \& Toporowski, 2013). Therefore, theorists and practitioners assume that suppliers always tend to circumvent buyers' requirements regarding environmental and social standards, especially if they impose additional costs on the supplier (Aßländer et al., 2016).

Agency theory is a useful tool for managers to diagnose and segregate their relationship portfolios, understanding and mitigating behavioral uncertainty (Fayezi, O'Loughlin, \& Zutshi, 2012). Both the principal(s) and the agent(s) tend to maximize their individual benefits. The development of this principal-agent relationship was derived from economic scholars through

\footnotetext{
(C) Raul Beal Partyka. Published in Revista de Gestão. Published by Emerald Publishing Limited. This article is published under the Creative Commons Attribution (CC BY 4.0) licence. Anyone may reproduce, distribute, translate and create derivative works of this article (for both commercial and noncommercial purposes), subject to full attribution to the original publication and authors. The full terms of this licence may be seen at http://creativecommons.org/licences/by/4.0/legalcode

Conflict of interest: We don't have any potential conflict of interest in the research.

This study was supported by The Coordination for the improvement of Higher Education Personnel (CAPES), Foundation within The Brazilian Ministry of Education.
}

Received 11 April 2021

Revised 30 June 2021

2 August 2021

Accepted 11 August 2021 
REGE 29,2

limited rationality, personal interest and the agent's risk aversion (Fitri, Elmanizar, Nugraha, Yakub, \& Cahyono, 2019). Relationships involving one company that delegates authority to another are common in the supply chain, for example, the principal-agent relationship exists in the case of supplier-managed inventory or long-term purchase contracts with automatic stock replenishment (Kros \& Nadler, 2010). Control is a fundamental principle of transport management in logistics (Miller, Saldanha, Hunt, \& Mello, 2013), in addition to the need for information, control and incentive mechanisms regarding moral hazard issues in contractual relationships of low- and high-performing responsive employees. Appropriate control mechanisms can prevent hidden actions and information (Kudla \& Klaas-Wissing, 2012).

Greater demand for sustainable behavior is also linked to adverse selection agency problems and moral hazards in dyadic relationships. The adverse selection problem identified in relation to people with poor responsive performance indicates a demand for evaluation and selection criteria for suitable partners (Kudla \& Klaas-Wissing, 2012). On the other hand, when outsourcing is involved, it brings information asymmetries in the development of initial contracts, which can lead to worse performance than initially expected. In this case, by applying agency theory, performance can be improved in the long run through the effective design of well-constructed contractual relationships (Sayed, Hendry, \& Zorzini Bell, 2020). With respect to traditional forms of financial performance (e.g. revenue, profit), these goals tend to lead to horizontal agency problems, for example in networks distributed throughout a franchise. In chains that use corporate-owned stores, vertical branch issues can become the main factor of non-compliance (Massimino \& Lawrence, 2019).

The theoretical lenses that agency theory provides can support managerial decisionmaking and strategy formulation, specifically with respect to relationships with suppliers and customers (Fayezi et al., 2012). Supply improvement initiatives lead to more collaborative relationships between buyer and supplier, thus lowering barriers to behavior-based approaches to managing supplier sustainability practices as prescribed by agency theory (Shafiq, Johnson, Klassen, \& Awaysheh, 2017). Monitoring can help buyers deal with an agent's opportunism as an integral part of relationship management (Heide, Wathne, \& Rokkan, 2007). However, in a contract manufacturing environment, neither severe external penalties nor frequent audits are able to fully align the quality interests of the parties (Handley \& Gray, 2013).

Aiming to raise new reflections, discussions and research, this review intends to answer the following research question: What are the absences and incipiencies of international scientific production in supply chain management from the agency theory perspective?

Among the types of systematic literature reviews, this one fits as an integrative review, i.e. a literature review method that aims to carry out various analyzes to expose the knowledge already raised by previous research (Botelho et al., 2011). Therefore, the number of published articles, number of citations, main authors and journals, for example, are analyzed. Based on the type of review used, motivation and contribution go together, that is, integrating the different opinions, concepts, results, ideas of the selected articles. This study also allows the evaluation of studies from the most diverse methodologies, either quantitative or qualitative. The bases of articles, whenever possible, were exported directly from the bases and inserted in the treatment software, avoiding possible errors due to incomplete information in the collection. Finally, the biggest challenge lies in presenting the discussion of results and suggesting future research in which the analysis and synthesis of the most diverse sources, themes and methods require compilation through extensive work.

Only two other articles sought to review the supply chain management literature that uses agency theory. While Fayezi et al. (2012) restrict their search to relationships within the supply chain, which analyzed 19 articles, Liu, Feng, Zhu, \& Sarkis (2018) focused on identifying the theories used in studies on green chain management and circular economy. As result, 12 theories emerged from the exploratory investigative study. Therefore, this research can be considered broader and unprecedented, since it carries out research without thematic 
limitation and without focusing only on theories or methods. It sheds light on international scientific production on supply chain management from the perspective of agency theory. The purpose is to unveil the publications and their characteristics and, above all, point out potential future research. 43 articles were identified, which primarily contribute to the understanding of the field. Agency theory can help managers to consider social, economic, political and behavioral aspects when making decisions about their contracts, through mechanisms of incentive, information sharing and goal congruence (Fayezi et al., 2012). A still latent challenge for supply chain managers interested in controlling sustainability risk is where and when to invest in behavior-oriented approaches to suppliers (Shafiq et al., 2017).

The next section addresses a literature review of the proposed theme. The following sections describe the methodological aspects, results, and conclusions, and research agenda proposed by the study.

\section{Supply chain management and agency theory}

Agency theory is largely dependent on two significant areas of inquiry, namely, positive agency theory and principal-agent theory. The first, as a descriptive theory, for understanding behaviors in the real world. The second, derived from economic scholars through limited rationality, individual interest and the agent's risk aversion. (Fitri, Elmanizar, Yakub, \& Cahyono, 2019). The final definition of the agent changes and may be linked to institutional differences of ownership within a supply chain. The agent is dynamic and will likely be the caretaker, and at the same time there is potential for the traditional definition of the agent to be challenged (Byrne \& Power, 2014).

Studying supply chain management phenomena can be enriched by providing theories from other related fields (Gligor, Bozkurt, Russo, \& Omar, 2019). Investigating sustainable strategy implementation from an internal agency relationship angle seems to be a good starting point. Amazon was exposed to massive negative headlines due to the unethical and illegal labor standards of its supplier, Foxconn. Adidas and Nike were exposed due to a Chinese textile supplier accused of dumping toxins into a river. In many organizations, there are demands beyond their direct control (Juttner, Windler, Podleisek, Gander, \& Meldau, 2020). The purchasing and supplier teams in firms should consider establishing a socially sustainable supply chain (Cole \& Aitken, 2019). On the other hand, monitoring the supplier's sustainability practices also has a positive effect on the performance of the focal company (Shafiq et al., 2017).

Due to the complexity of some supply chains, downstream companies can only monitor the relationship with their direct suppliers, but not the suppliers' suppliers (Wiese \& Toporowski, 2013). From the retailers' perspective, they have a right to be suspicious when engaging in category management relationships with focal suppliers. Monitoring and the ability to punish opportunistic behavior do not necessarily act as effective safeguards. The opportunistic behavior of a focal supplier provokes responses from other suppliers, in addition to having a direct negative impact on the retailer's performance. These dynamics also occur in other industries, such as electronics and automotive (Morgan, Kaleka, \& Gooner, 2007). The threat of opportunism can cause companies to withhold certain inside information when sharing chain risk information with partners (Ciliberti, De Haan, De Groot, \& Pontrandolfo, 2011).

In the same scenario, the content of the contract mechanism and its implementation (such as benefits, problems and success factors) were described and discussed using an alignment of incentives and agency theory framework. Assumptions include information asymmetry, different goals and opportunism that should not be neglected. In order to solve agency and risk-sharing problems in principal-agent relationships, agency theory prescribes two formal (and ideal) types of management mechanisms to govern these relationships (Rungtusanatham, Rabinovich, Ashenbaum, \& Wallin, 2007). One is the results-based
Supply chain management 
REGE

29,2

management mechanism. On this, tops reward agents based on measured performance results (Ekanayake, 2004), regardless of how agents reach them (Choi \& Liker, 1995). The other, management mechanism is behavior-based. Principals use behavior controls to monitor the behavior and activities of agents that are unknown to principals ( $\mathrm{Zu} \&$ Kaynak, 2012).

Two service providers (acting as agents for the customer from a contractual point of view) are also the main ones for the customer and the customer's business partners when it comes to service delivery, as the customer requires certain inputs to ensure performance achievement (Selviaridis \& Norrman, 2014). The role of what we call a "double agency" encompasses the first-tier supplier's responsibility to act as an agent for the lead company by implementing sustainability in their own operations (e.g. the lead agency function) and acting as an agent to disseminate sustainability standards for its suppliers' operations (e.g. secondary agency function). That is, incentives are effective at both agency levels, but the importance of information transparency is greater at the secondary agency level (Wilhelm, Blome, Bhakoo, \& Paulraj, 2016).

\section{Method}

The literature review received different terms in the literature. This is an integrative review, belonging to systematic literature review studies (Whittemore \& Knafl, 2005). The integrative review process detailed by Botelho et al. (2011) was used, which mention that the method allows making summaries of the state of the art, in addition to understanding the increasing amount and complexity of information on a given subject. This study analyzes the international literature on the use of agency theory in supply chain management articles. The two search terms were: "supply chain" and "agency theory". The terms were included in the study derived from reading numerous articles, but only those that explicitly mentioned the two words were used.

The research originated from articles from the Scopus and Web of Science databases and examined all the years available in the databases. In summary, Table 1 presents the general characteristics of the research, this allows other researchers to replicate the study. When entering the query for the search terms, a total of 205 articles were found. With Microsoft Excel software, records were organized and selected according to the following filters: the two search terms in the abstract, in title or the keywords; journal articles and review articles and only journals on (1) management, business, and accounting, (2) economics and finance, (3) operations and (4) decision science, reaching 124 articles. In a final analysis, with the reading of the title, abstract and keywords to validate the relevance to the study subject, supply chain management and removal of duplicate articles between the bases, 56 relevant articles were selected and will be used for analysis. The list of articles and their authors is available in Appendix. A cocitation analysis was also performed, created using the VOSviewer version

$\begin{array}{ll}\begin{array}{l}\text { Search terms } \\ \begin{array}{l}\text { Development } \\ \text { date }\end{array}\end{array} & \begin{array}{l}\text { "supply chain" AND "agency theory" } \\ \text { Sources }\end{array} \\ \text { Filters } & \begin{array}{l}\text { Scopus e Web of Science } \\ \text { Scopus: } 1960 \text { to } 2021 \text { (June) }\end{array} \\ & \begin{array}{l}\text { Web of Science: } 1945 \text { to } 2021 \text { (June) } \\ \text { Only words contained in the title, abstract or keywords }\end{array} \\ & \begin{array}{l}\text { Articles or review articles only } \\ \text { Only in journals of 1) management, business and accounting, 2) economics and finance, 3) } \\ \text { operations and 4) decision science }\end{array}\end{array}$

Table 1.

Features of integrative review 
1.6.16 software. Data were originated from the two research bases (Scopus and WOS), without any manipulation. Therefore, with the articles found in the databases, an analysis of the cocitation network of authors was performed, using as a criterion author with at least 25 citations. The relationship diagram of terms presents in the title and abstract of selected articles was also developed. For this analysis, terms with the occurrence of 10 times or more were reported.

The next chapter deals with the analysis and presentation of the findings from the methods used. The following analyzes are related: (1) evolution of research over the years, (2) journals that published research on the topic, (3) authors that published the most, (4) cocitation network of the respective authors, (5) analysis of the affiliation of authors, (6) analysis of the keywords adopted by the authors in their articles, (7) the theories used by the authors, (8) the chosen themes, (9) relationship diagram of the terms of the title and abstract of the articles, (10) analysis of the method used by the authors and statistical analyses, for quantitative articles, (11) the geographic location of the empirical field of the articles and, finally, (12) description of the five most cited articles, regarding the research question, findings and research gaps.

\section{Analysis and findings}

This research started with the description of the characteristics of the dataset of 57 articles. An upward trend of publications in supply chain management from the agency theory perspective only happened from the year 2019, losing strength in 2020, which may indicate that this is an atypical year. However, more than $50 \%$ of the articles were published in the last five years between 2016 and 2021 (June). Figure 1 shows the historical evolution of the records of published articles. It is possible to notice that, despite being timid, there is a propensity for the evolution of research publication, when observing the period from 1996 (first publication) to 2019. However, in the last two years, there has been a decline in research on the theme.

Table 2 shows the articles categorized by the respective publishing journals, with two or more articles published. There are a total of 12 journals classified according to the criteria described. The International Journal of Supply Chain Management has the largest number of articles, with five publications, the same number as the Supply Chain Management journal. The highlight to be given in this section is because, together, the 11 journals have only $25 \%$ of the total articles selected for research analysis. That is, there is no unanimity of scientific journal for submission and a consequent approval of the article that is chosen by the authors of articles on supply chain management using the agency theory.

In the analysis of authors who publish on the topic, among those who have two or more articles published, the author who has published the most on supply chain management, using the agency theory, is Jason W. Miller, with four publications (Table 3). Three are as a first author and one as a third author. Miller is an Associate Professor in the Department of Supply Chain Management at the Broad College of Business at Michigan State University.

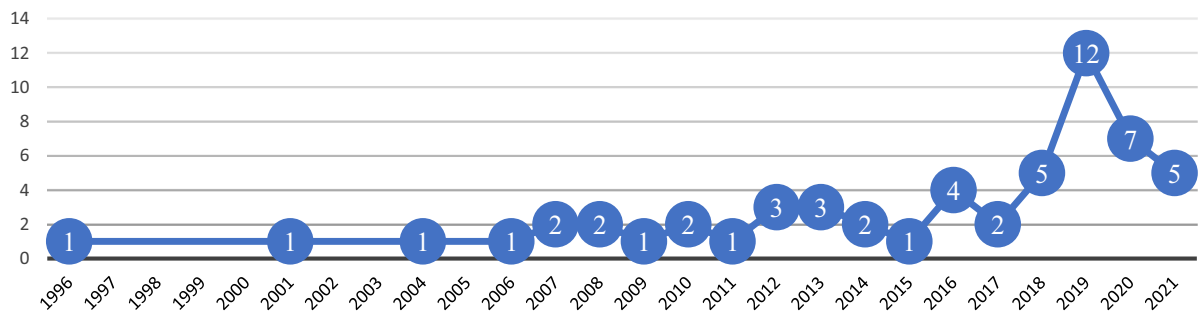

Source(s): Research data
Supply chain management
Figure 1. Articles timeline 
REGE 29,2

\begin{tabular}{ll}
\hline \# Articles & Journal \\
\hline 5 & International Journal of Supply Chain Management \\
4 & $\begin{array}{l}\text { Supply Chain Management } \\
\text { International Journal of Operations \& Production Management } \\
\text { International Journal of Production Economics } \\
\text { Journal of Business Logistics }\end{array}$ \\
& $\begin{array}{l}\text { Journal of Operations Management } \\
\text { International Journal of Physical Distribution \& Logistics Management }\end{array}$ \\
& $\begin{array}{l}\text { Production Planning and Control } \\
\text { Journal of Enterprise Information Management }\end{array}$ \\
Journal of Purchasing and Supply Management \\
Supply Chain Management: An International Journal
\end{tabular}

Taurnals with more published articles

\begin{tabular}{ll}
\hline \# Articles & Author \\
\hline 4 & Miller, J. W. \\
3 & Norrman, A. \\
2 & Anwar, A. \\
& Ellram, L. M. \\
\multicolumn{2}{l}{ Source(s): Research data }
\end{tabular}

With four publications, Miller has 20 citations in his most cited article (Miller, 2017). The second author with more publications is Andreas Norrman, from Lund University, with three articles, being two articles as first author and the third as second author. Following, in the same quantity, of two articles published, are: Asep Anwar, from Widyatama University, both publications as third author; Mohd S. B. A. Razimi, Northern University of Malaysia, both publications as fourth author and Lisa M. Ellram of Miami University, one publication as first author and the other as second author. The point that deserves to be highlighted is that, even if the publications among authors with more than two articles published (nine articles) are added together, this corresponds to only approximately $20 \%$ of the total number of publications on the subject. Evidence points to a dispersion of research among authors and, when considering the years with publications (Table 3), a moment of seeking consolidation of themes.

Figure 2 shows the cocitation network of the authors of the articles in the analysis. Three clusters were obtained, for the parameter of at least 25 citations of each author. A total of nine authors are listed. Lisa M. Ellram (from Miami University) has 62 citations and leads. While, with 61 citations, is Kathleen M. Eisenhardt (of Stanford University). With the same number of citations, in third place, are Thomas Y. Choi (from Arizona State University) and George A. Zsidisin (from the University of Missouri), with 33 citations.

Cluster one is indicated by red. Kathleen M. Eisenhardt is at the center of this cluster, which is cited by eight other researchers. Despite Eisenhardt's unanimity, the other members of the cluster (Jan B. Heide (26), from the University of Wisconsin-Madison, Thomas M. Corsi (26), from the University of Maryland College Park and John T. Mentzer (25) from the University of Tennessee) are predominantly related to research involving transport and logistics, inter-firm relationships and supply chain risk.

Cluster two is represented by green. This is composed by researcher Lisa M. Ellram, who has the highest number of citations. The congruent factor in this group, which also comprises 


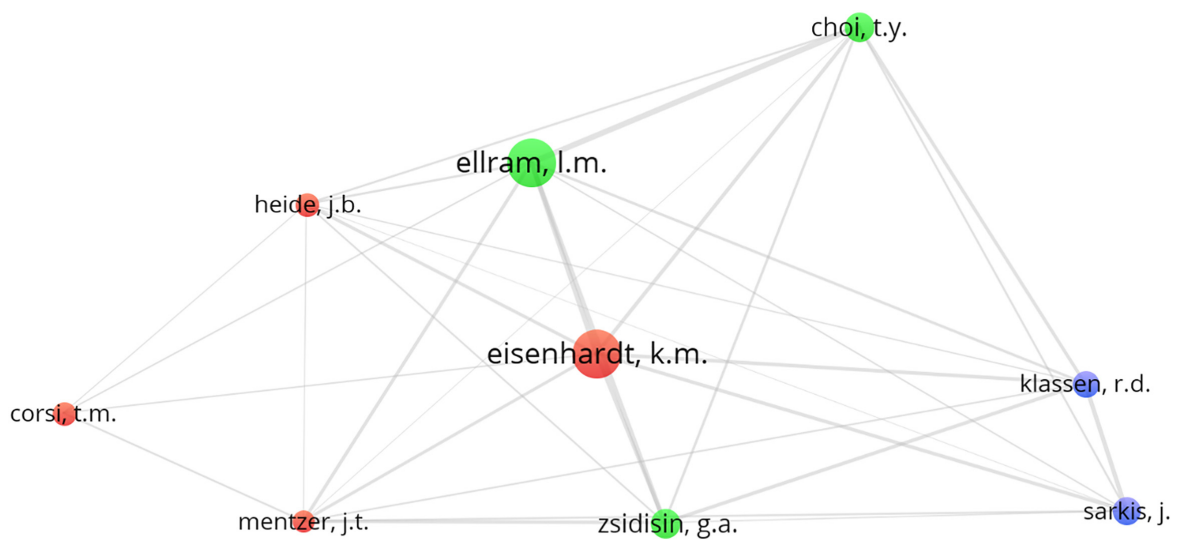

Source(s): Prepared by the author, using VOSviewer 1.6.16

Thomas Y. Choi and George A. Zsidisin, is supply chain management strategies and the study of methods used by researchers in the field. There is also a predominance of the case study method in the publications of the two researchers.

Cluster three, indicated by blue, is composed of two researchers. Robert D. Klassen (30) of Western University and Joseph Sarkis (31) of Worcester Polytechnic Institute. The congruence between the authors lies in the theme of sustainability and the study of green supply chain management.

When analyzing the geographic sample of affiliation of the authors of the articles (Figure 3), it is possible to observe a strong predominance of affiliated researchers in institutions in the United States of America (USA), with 42 researchers. Second, with a $45 \%$ smaller presence, researchers from the United Kingdom (23) and third researchers from Malaysia (16).

Table 4 shows the most cited keywords, with two or more appearances, in the original form presented in the articles, that is, those chosen by the authors. A total of 158 keywords were collected. The most found keyword is "agency theory", in more than half of the articles

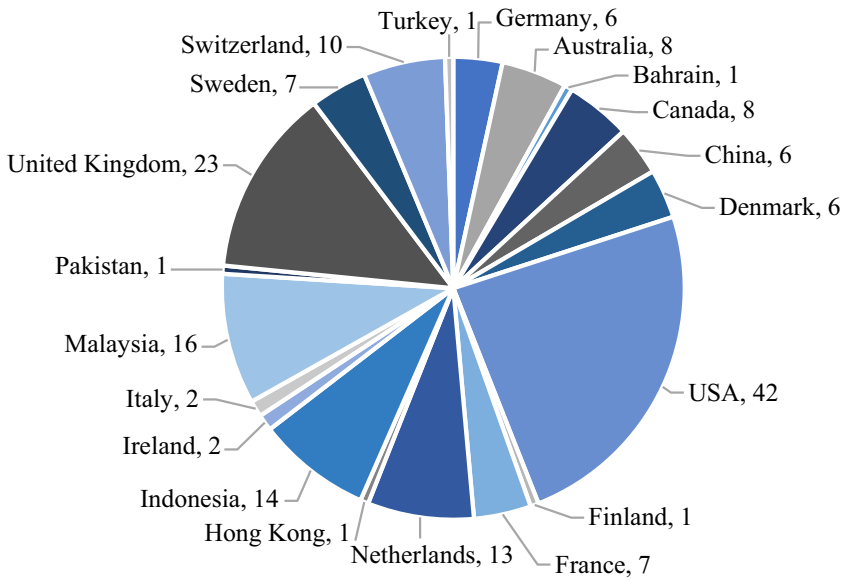

Source(s): Research data

Figure 3. Geographical description of the authors' affiliation 


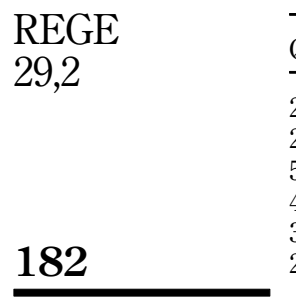

Table 4. Most used keywords

\section{Qty Keyword}

25 Agency theory

22 Supply chain management

5 Indonesia; Sustainability

4 Case studies; Sustainable supply chain management

3 Collaboration; Purchases; Relationship with suppliers; Outsourcing

2 Agency theory perspective; Agent; Buyer-supplier relationship; Communications; Compliance; Corporate social responsibility; Europe; Goal congruence; Incentive alignment; Integration; Literature review; Logistic service industry; Motor carrier; Multi-tier supply chains; Network theory; Purchasing; Quality management; Risk assessment; Risk management; Safety; Service triads; SME; Supplier monitoring

Source(s): Research data

$(51.16 \%)$. The second with the highest number of appearances is "supply chain management", which appeared 20 times $(46.51 \%)$. Although there is a filter for keywords that occurred at least twice, from the third most frequent keyword there was a drastic drop, with the Indonesia keyword being the one that appeared in third place, in only five articles $(11.63 \%)$. With that said, it is possible to infer that there is a great dispersion of alternative themes in the construction of research on agency theory in supply chain management.

The results also contribute by revealing a theoretical and multidisciplinary diversity of studies, with the number of appearances of theories underlying the agency theory, as shown in Table 5. Considering theories with two or more appearances, with seven appearances, the transaction cost theory is the theory that most closely follows agency theory, with more than $16 \%$ of all studies. The second, the resource-based view, with four appearances. The third is network theory. Finally, with two appearances, another six theories were registered. The salient point is that, together, these underlying theories occurred in approximately $37 \%$ of the selected articles. In other words, there is no predominance of theories underlying agency theory in supply chain management research.

When considering the low occurrence of a secondary theoretical construct, it was also decided to classify the articles by thematic (Table 6), presenting those with two or more

Table 5.

Most used subjacent theories

\section{Qty Theory}

7 Transaction cost theory

4 Resource-based view

3 Network theory

2 Collaborative approach; Institutional theory; Principal agency theory (PAT); Resource dependency theory; SCM; Sociological agency theory

Source(s): Research data

Table 6.

\begin{tabular}{ll} 
Qty & Theme \\
\hline 8 & Performance \\
5 & Risk in supply chain; Sustainability \\
4 & Dyadic relationships; Inter-firm relationships; Supplier management \\
3 & Supply chain quality management; Supply chain relationship \\
2 & Service supply chains; Socially responsible
\end{tabular}

The most used themes Source(s): Research data 
appearances. This makes it even clearer, due to the dispersion presented above, about which of the themes are the most used by authors when they decide to use agency theory in supply chain management. The most common theme is performance, but in only eight articles $(14.29 \%)$. The second theme "risk in supply chain" and "sustainability" has the same number of articles (five, $8.93 \%$ ) among the 56 in the sample. In third place, with four appearances $(7.14 \%)$ each, are the themes: dyadic relationships, inter-firm relationships and supplier management. Analytically, it is possible to say that, predominantly, research in supply chain management that uses the agency theory, as a base theory, is related to performance (which can be, financial, sustainable, safety, operational, logistics or from the chain).

To support the findings, an analysis using the term identification function, both in the title and in the abstract of the articles, was performed using the VOSviewer software. The databases originated from Scopus and WOS were exported and did not have any intervention. After being inserted in the software, as a result, the term relationship diagram was built (Figure 4). The terms with the occurrence of 10 times or more are reported, with the most present terms being study (90), relationship (71) e-supply chain (66). Thus, in the diagram, three distinct clusters could be obtained. The first cluster (red) deals with themes of supply chain management, which involves the managers, the data collected through them and some theory for the explanation. In the second cluster (green), there is the thematic relationship in the supply chain, which involves buyer, supplier and the result. Finally, the third cluster (blue), dealing with the supply chain with the firm's risk and sustainability aspects.

Regarding the methods used by the authors of the articles in the sample (Table 7), they were separated into quantitative (using secondary data) and qualitative (and their approaches). The most used is quantitative, appearing in 25 articles, that is, less than half of the 56 total $(44.64 \%)$. Furthermore, one article in the sample used a multimethod.

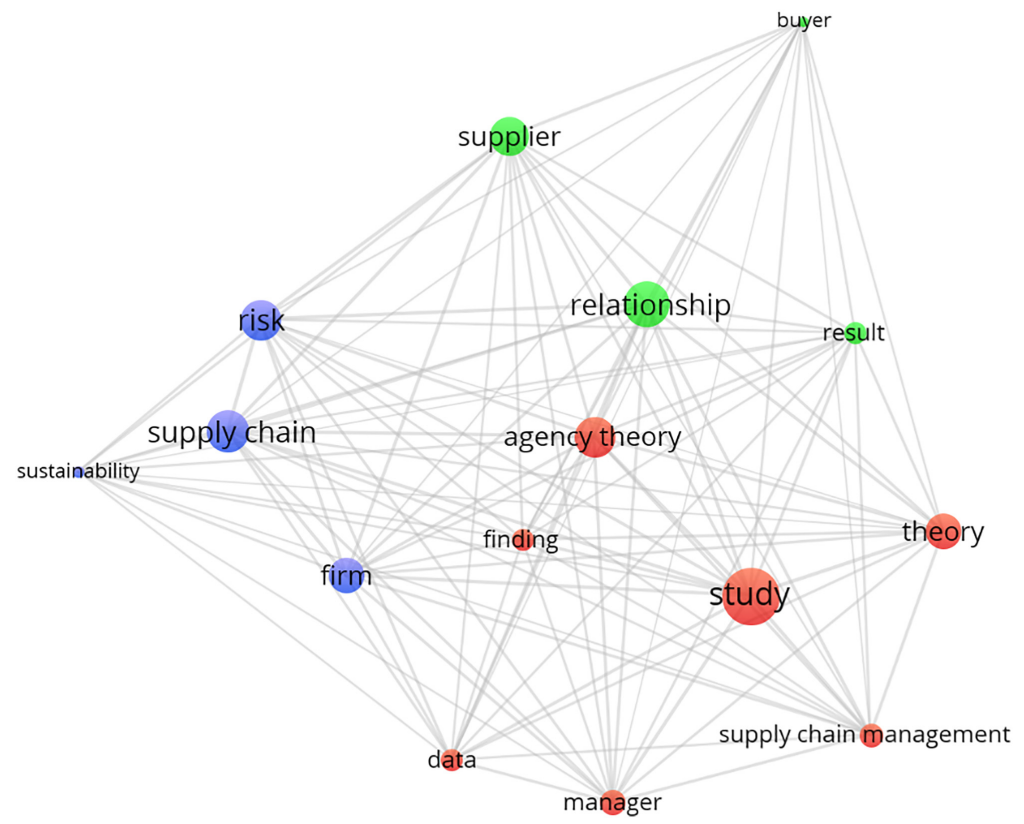

Source(s): Prepared by the author, using VOSviewer 1.6.16
Supply chain management

183 
REGE

29,2

\section{4}

When looking at the qualitative method, only 4 (7.14\% of the total sample). However, when qualitative approaches were observed, the case study method was used in 18 articles $(60 \%)$. Still with two percentage digits $(20 \%)$, within the qualitative approaches, the theoretical essay appears with six publications. The findings of the methods used corroborate the themes of the articles, as, usually, studies related to performance are built using the quantitative method. Thus, the thematic performance, as it was the most found, may have been the main responsible for boosting the quantitative method to be the most registered in the analysis of the articles in the sample.

Considering the predominance of quantitative research, the data analysis techniques used by the authors were detailed. The most used technique is structural equation modeling, which is used in 13 of the 25 quantitative articles. Second, the regression, in six articles. And in third place, the regression with panel data with two articles. Likewise, using the rationale of the most frequent theme (performance) evidenced in the sample articles, and by the method that occurs most frequently (quantitative), it is found that the authors analyze statistically, predominantly, through structural equation modeling and panel data regression and regression to explain performance in supply chain management articles that use agency theory. The results are consistent with performance studies, as they seek to causally explain the variables that explain the variation in firm performance. Therefore, the techniques found are those commonly used for this purpose (see Table 8).

One of the highlights of this study is the analysis performed to identify the geographic identity of each of the articles in the sample, shown in Figure 5. There is a large predominance of surveys with data from the United States (13), followed by data from Indonesia (6) and after the European continent (5). The point in emphasis is that there were no studies that used Brazilian data.

Finally, Table 9 identifies the five most cited articles, which can also be called the five most influential articles. The research question, findings and research gaps are presented, respectively. By observing the research questions, the most cited article and the third one can

\begin{tabular}{lrrlrc}
\hline Type & Qty & $\%$ & Type & Qty & $\%$ \\
\hline Quantitative & 25 & 96.15 & Qualitative & 4 & 13.33 \\
Multimethod & 1 & 3.85 & - Case study & 18 & 60 \\
& & & - Theoretical essay & 6 & 20 \\
Total & 26 & 100 & - Literature review & 2 & 6.67 \\
Total & & & 30 & 100
\end{tabular}

Table 7.
The methods used

The methods used Source(s): Research data

\begin{tabular}{lrr}
\hline Type & Qty & $\%$ \\
\hline Structural equation modeling & 13 & 52 \\
Regression & 6 & 24 \\
Panel data & 2 & 8 \\
Diff-in-diff & 1 & 4 \\
Path analysis & 1 & 4 \\
ANOVA/MANOVA & 1 & 4 \\
$T$-test & 1 & 4 \\
Total & 25 & 100 \\
Source(s): Research data & & \\
\hline
\end{tabular}




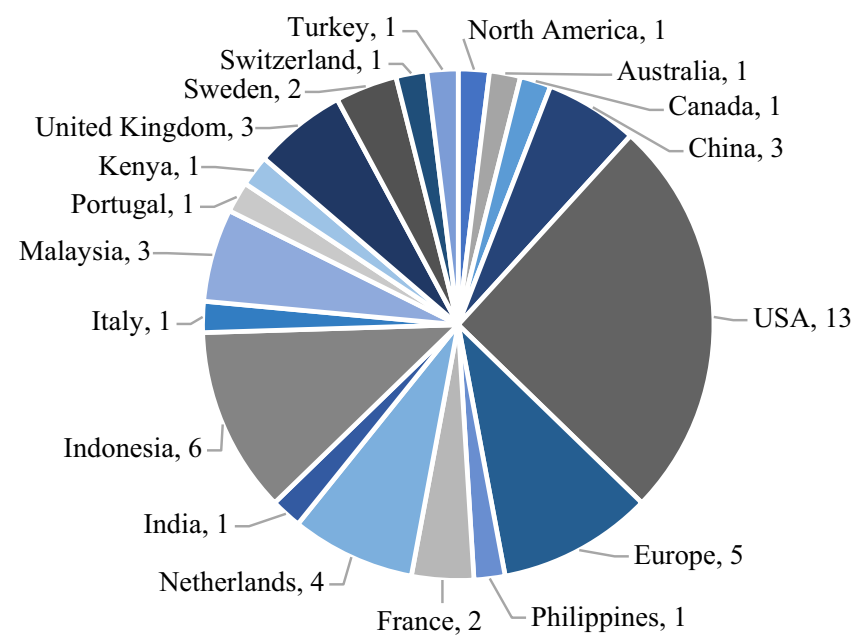

Source(s): Research data

Figure 5. Geographical description of the sample of articles

be grouped within the supply chain risk theme. The second most cited, in sustainability, and the fourth and fifth most cited, in the theme of supply chain relationships. Looking at the research gaps, it is noteworthy that the most cited article uses a cross-sectional analysis, without being able to analyze longitudinally, which, in fact, could verify the effect of supply risk on performance. The same gap is observed in the third most cited, using longitudinal research to test causal relationships. Something similar is also observed in the second most cited, where it indicates the need for research in more than one layer of the supply chain. From the latter, the fourth most cited article exposes that further exploration is needed of the impact of relationships with a supplier and how much this relationship has an influence on relationships with other suppliers. The fifth most cited article is more provocative, intended to instigate research on the premises of supply chain relationships.

\section{Discussion of the results}

Based on the results obtained, it is important to compile what is being repeated and what is still incipient. Therefore, clearly, from the sample articles, while some studies tend to focus on discussing the antecedents and consequences of agency problems, others tend to identify practices for managing agency problems. In this perspective, this article contributes by summarizing and unifying the contributions and limitations (potential future research) to clarify and be a platform for further research. As seen in the evolution of research on the subject, the field has recently declined and, therefore, it is essential that additional tools to those of researchers motivated by their personal convictions can be presented and used, to facilitate and promulgate studies on the agency theory in the supply chain, especially regarding management.

Two main challenges decision-makers face in managing intermediaries: (1) objective incongruence, where the agent and principal may have widely divergent priorities and (2) incomplete or asymmetric information, where the principal has limited intelligence about the activities of the agent (Figure 6) (Eisenhardt, 1989).

The first question for both challenges: are agents capable of doing what they say they are going to do? Here the problem of alignment arises (Wallace, Johnson, \& Umesh, 2009) or the information asymmetry, as a source of the perceptual distance between the collaborating parties (van der Krift, van Weele, \& Gevers, 2021). In this case, to increase the efficiency of 
REGE

29,2

186

Table 9.

The five most cited articles

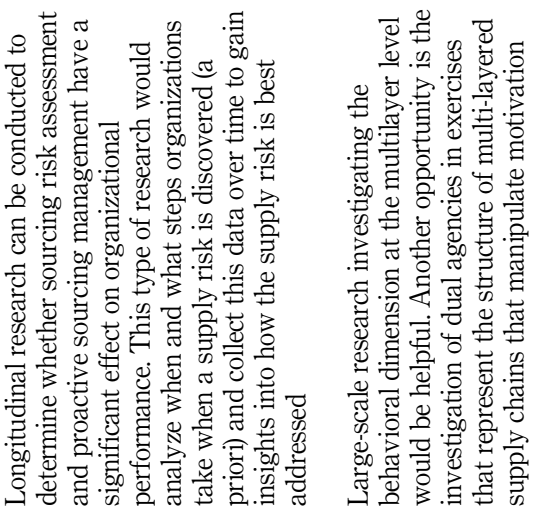

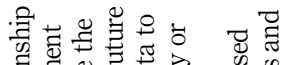

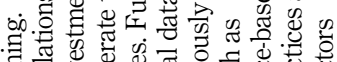

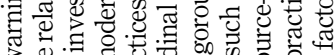

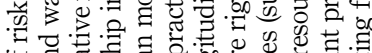

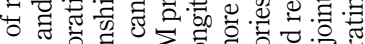

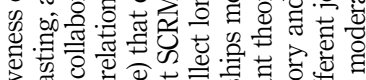
论

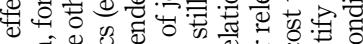

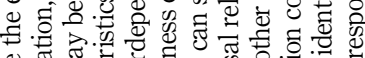

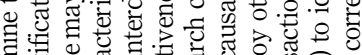

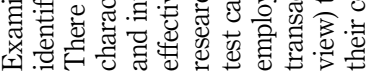

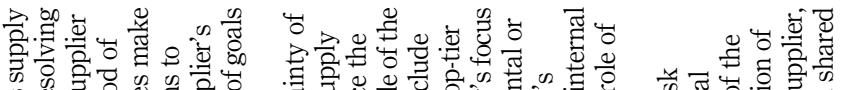

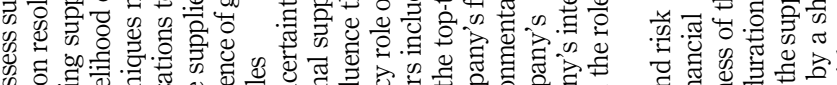

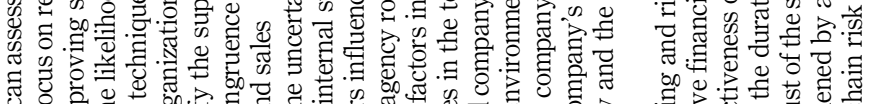

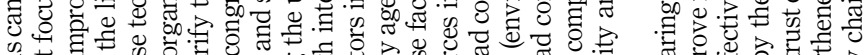

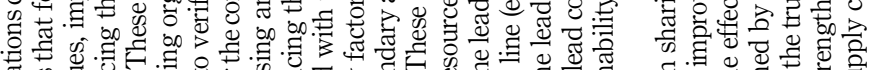

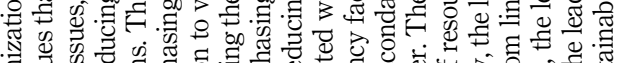

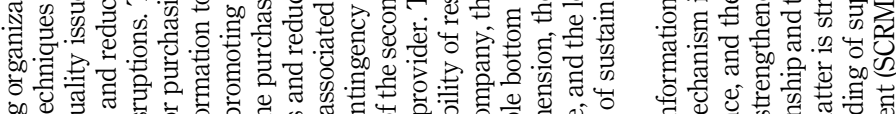
o

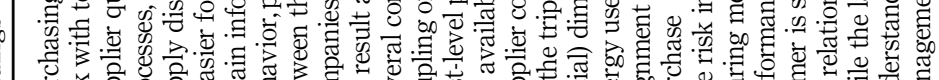

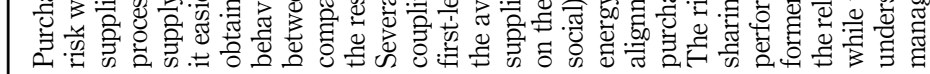

至望

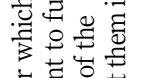

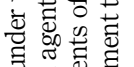

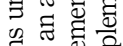

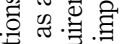

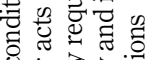

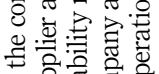

‡) 을

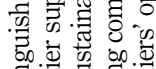

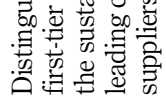

๙ิ

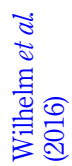

N

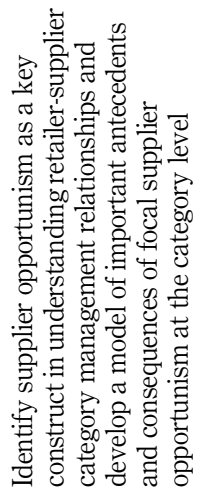

$\stackrel{\varrho}{=}$

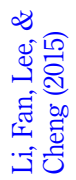

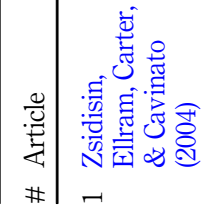




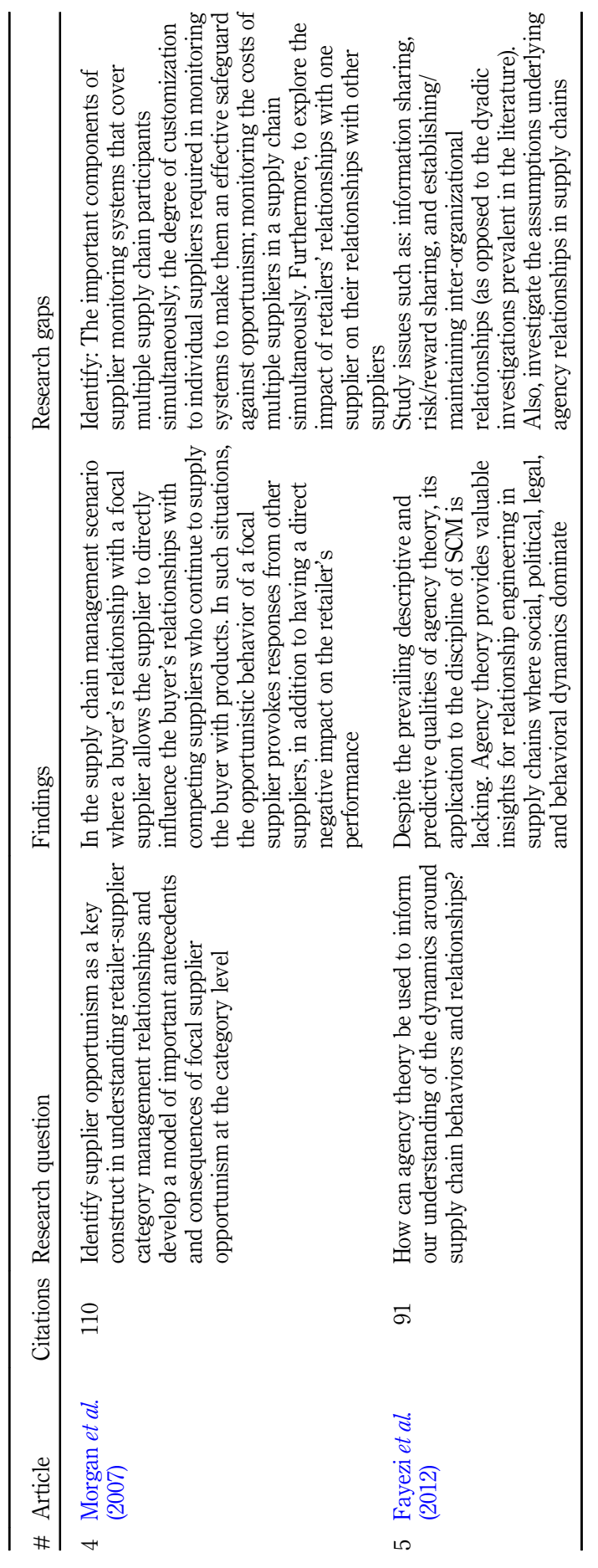


REGE

29,2

\section{8}

Figure 6.

Challenges of agency

theory in the

supply chain

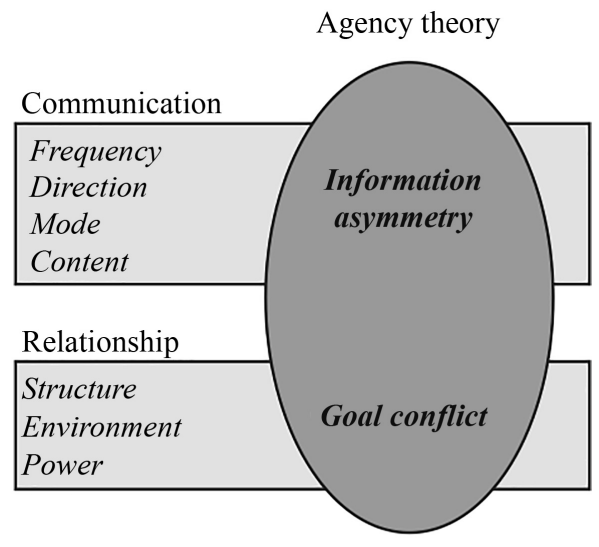

Source(s): Forslund, Björklund and Ülgen (2021, p. 5)

behavioral practices, that is, risk and reward sharing, companies must have a low level of information asymmetry in the supply chain (Tse, Zhang, \& Jia, 2018). As companies become more transparent and accountable, it reduces information asymmetries (Gong, Gao, Koh, Sutcliffe, \& Cullen, 2019). However, if each function holds its own information and goals, it is easy to hide information from other functions, especially if they are operating in a high uncertainty environment (Ellram, Tate, \& Choi, 2020). In other words, an aligned supply chain needs the exchange of relevant information and, therefore, long-term relationships and trust with partners (Wandfluh, Hofmann, \& Schoensleben, 2016).

On the other hand, in an ex-post setting, the second challenge: did agents do what they said they would? Here arises the moral problem (Wallace et al., 2009). Agency uncertainties (e.g. supply risks) can be mitigated by adopting the behavior-based method, promoting supplier information, integrity (trust) and quality assurance, in order to reduce the likelihood of partner opportunism (Azmi, Musa, Chew, \& Jagiripu, 2021).

From the following paragraph, the themes found are listed and the most important aspects for the study topic are exposed, based on the analyzed articles.

Dyads: Agency theory can shed light on dyadic inter-firm relationships (Cragg \& McNamara, 2018). While agency theory seeks to address a multitude of different professional, social, political and economic circumstances, one thing unanimous about all principal-agent relationships, without hesitation, is that there will be problems (Shapiro, 2005).

Giving a volume commitment can be a way to signal confidence in the forecast itself, as well as in a long-term relationship; which can increase trust and improve the relationship, which may result in the supplier providing guaranteed supply in allocation situations, as well as lower unit prices (Norrman, 2008). Many supply chains are not linear when it comes to contracts: there can be multiple formalized relationships between and over layers, making them very complex. A business cycle perspective could be incorporated into the contract (Norrman, 2008). While previous research on tracking capabilities has focused on bilateral relationships between a buyer and a single supplier, many retailers sell products that come from multiple suppliers. Therefore, there is still a lot of discoveries to be made about how monitoring capabilities work in a supplier network context (Morgan et al., 2007). However, monitoring is associated with negative effects on supplier behavior and there is an implication of costs (Uenk \& Telgen, 2019), which is in agreement with the result found from the transaction costs theory as the main theory underlying the agency theory. 
When the context is small- and medium-sized companies, the asymmetric nature of their relationships (importing firms) with international suppliers, generate agency problems putting them at a disadvantage (Cragg \& McNamara, 2018). A large proportion of data from small- and medium-sized companies resulted in limited information content, which only reflects performance in a particular small group. In contrast to small- and medium-sized companies, companies that have more resources can more easily attract their supplier companies to be involved in the initial manufacturing process and lead the task scheduling (Tse et al., 2018). As a resolution, the use of partnerships and consortia together with better design contracting and greater information sharing can mitigate the asymmetry of power in the relationship (Cragg \& McNamara, 2018).

Triads: Agency problems can occur in service triads due to incongruity of goals between principals and agents arising from assumptions about human nature (self-interest, limited rationality, risk aversion) (Uenk \& Telgen, 2019). Studies typically conclude that buyers need to monitor performance and implement the type of contracts (Tate, Ellram, Bals, Hartmann, \& van der Valk, 2010; Van der Valk \& Van Iwaarden, 2011). The once in a while service triads employ a maintenance partner (third party), who is in frequent contact with the end customer and who therefore has a significant role in influencing the service output of the main provider (Heaslip \& Kovács, 2019).

In several contexts, studies confirm the need to monitor supplier performance in service triads (Tate et al., 2010; Zhang, Lawrence, \& Anderson, 2015). Monitoring can be directed to any supplier outcome or supplier behavior (Uenk \& Telgen, 2019).

Sustainability: The application of agency theory resulted in a deeper analysis of sustainability approaches beyond dyads (Aßländer et al., 2016; Kudla \& Klaas-Wissing, 2012). When the motivation of sustainability initiatives is to meet personal goals, a more transparent environment should reduce sustainability and sustainable supply chain management (SSCM), as the company will not be willing to disclose these activities. However, if the motivation is to gain a competitive advantage, a more transparent way will encourage sustainability (Gong et al., 2019).

Agency theory helps to identify dual roles, that is, an agent who reports to the principal and collaborates with other agents to meet the requirements (Forslund, Björklund, \& Ülgen, 2021) and to understand and explore how companies within an eco-industrial park establish relationships (agent) with a third party, contracting services such as logistics or sewage collection (Liu, Feng, Zhu, \& Sarkis, 2018). Also within the theme, the so-called double agency makes the agent responsible for achieving goals in two ways: (1) to implement sustainability internally (main) and ii) to expand sustainability standards to its suppliers (secondary agency) (Wilhelm et al., 2016). In the context, the agency's vision is used to create barriers so that sustainable practices financed by managerial income are not diverted by executives, who may choose to divert such revenues to social and environmental initiatives of their personal interest (Gong et al., 2019).

Distribution channels: A strategic imperative across the industry, multichannel distribution is related to agency theory where channel alignment problems occur in the form of incomplete information and goal incongruity (Wallace et al., 2009).

Managers can increase their company's market coverage, either through delivery performance or profitability through multi-channel strategies, but these benefits run the risk of serious agency problems - which can at least be improved with channel tracking (Wallace et al., 2009).

Risks: Common principal-agent relationship problems, such as opportunism, differences in objectives and risks, and information asymmetry, can compromise the effectiveness of risk mitigation practices in the supply chain. Differences in risk goals and attitudes make it difficult for supply chain partners to reach consensus on methods for sharing roles to mitigate chain risks and, most importantly, address the consequences of these. (Li et al., 2015).
Supply chain management 
REGE

29,2

The study by Miller et al. (2013) demonstrated as complementary the agency theory, operant conditioning theory, and psychological reactance theory, in order to provide an integrated perspective on the use of formal controls to influence the behavior of drivers and thus improve operational performance. According Wilhelm et al. (2016) integrating a behavioral perspective would enrich understanding of the root causes of vendors violating their dual agency role. Moreover, the crucial role of supplier management in regional subsidiaries points to the need for a cultural and behavioral change in the purchasing function (Juttner et al., 2020).

Agency theory instruments can help avoid risks or failure to mitigate them in supply chains (Wiese \& Toporowski, 2013) as well as improvements in the operational processes of the supply chain can reduce the asymmetry of information and reduce the propensity for moral hazard (Shafiq et al., 2017). It is a fact that the successful implementation of supply chain processes and activities can be provided by meeting the agent's specific conditions through a dynamic contractual relationship (Fayezi et al., 2012). An in-depth analysis of strategic collaboration alliances was also noted (Lechler, Canzaniello, \& Hartmann, 2019), while risk reduction techniques are considered behavior-based management efforts to protect the principal from destructive events (Shafiq et al., 2017).

Quality: The greater the increase in supply risk, the greater the agency effort in managing traceability (Azmi et al., 2021). Supplier involvement allows buyers to clarify the capability, role and performance of their suppliers; thus, purchasing companies can more easily design and implement effective risk sharing with their suppliers. Therefore, it likewise occurs when the buyer shares the benefits and rewards of product quality improvement with the supplier, an alignment of goals occurs so that the supplier shares the buyer's goal of sustaining product quality. (Tse et al., 2018).

Reward sharing can be an effective practice to solve agency problems in buyer-supplier relationships ( $\mathrm{Zu} \&$ Kaynak, 2012). Allowing customers (end customers) to choose their supplier (of service) and facilitating the exchange of providers can offer a completely different, but strong, mechanism to avoid supplier opportunism and improve or maintain service quality levels (Uenk \& Telgen, 2019).

Third sector: The power that NGOs and certification bodies wield is not static; rather, they change with the role of buyer regulations and mandates (Wilhelm et al., 2016). The problem of hidden intentions requires a more detailed analysis (Wiese \& Toporowski, 2013) as well as an investigation of entry barriers for strategic alliances (Lechler et al., 2019). However, the idea that estimated trust can be developed and controlled through goal alignment suggests the potential for a deeper understanding of the mechanisms that underpin the principal-agent relationship (Byrne \& Power, 2014).

\section{Conclusion and future research}

Agency problems were considered less serious when dealing with upstream partners (Cragg \& McNamara, 2018). On the other hand, effective management of agency relationships in the downstream channel is critical to ensure strategic and performance results (Wallace et al., 2009). Future research may focus on explaining how weak ties can offer new ways to gain access to resources beyond triad boundaries and how triad actors institutionalize structural, relational and cognitive embeddedness (Vlachos \& Dyra, 2020). Therefore, information and power are at the heart of agency theory. The inclusion of institutional differences in agency theory would create a more comprehensive theory, better able to explain some of the nuances that exist in supply chain relationships and principal-agent relationships (Byrne \& Power, 2014).

The tension between voluntary compliance (e.g. specialized training regimes or additional corporate support for small franchised establishments) and mandatory compliance is an 
interesting trade-off and provides an interesting topic for future work (Massimino \& Lawrence, 2019), such as the investigation of the impact of the electronic point at the industry level in relation to carrier producer prices, driver turnover rates, changes in employment, average spot market rates, among others (Miller, Bolumole, \& Schwieterman, 2020). No studies have examined how control regimes influence driver-level outcomes, considering the different levels of professionalism and bonding strength between vehicle operators in different ways (Miller et al., 2013).

As noted earlier, in the geographic description, there is no empirical data about Brazil in the articles analyzed. This makes clear a future opportunity for investigations that contemplate data from Brazilian companies in supply chain management studies that use agency theory. Future research may also include geopolitical and product factors, along with supply factors, to present an assessment of environmental factors that favor supply risk (Shafiq et al., 2017). New investigations could collect longitudinal data (Wilhelm et al., 2016) for the purpose to test the causal relationships in the hypotheses (Li et al., 2015), and increase confidence in the causal nature of relationships (Morgan et al., 2007). Longitudinal research can also be conducted to analyze when and what steps organizations take when a supply risk is discovered (the above) and how the supply risk is best addressed (Zsidisin et al., 2004). An in-depth investigation into the broader consequences of supply risk, such as its effect on sustainability and supply chain practices, is still needed (Shafiq et al., 2017). Contexts of developed markets, highly resolved in terms of sustainability are already known, therefore, research on sustainability in another geographic context will generate different and interesting results (Forslund et al., 2021). Still regarding methods, it is relevant to carry out investigations of the action research type, where the proposals are actually implemented and a real performance measurement is carried out, especially if there is a quantification of the real performance changes due to the implementation of communication technology and information (Cragg \& McNamara, 2018).

In the macro environment, purchasing has a potential agency problem in the form of incongruity between the goal of new product development and its responsibility for continuous cost reduction (Ellram et al., 2020). It is opportune to conduct studies with companies in border and emerging countries as buyers (Wandfluh et al., 2016). Different countries also have alternate views on the practice of risk management, which affects the outcome (Tse et al., 2018). Reducing to the dynamic business environment, the integration of business processes (as in the supply chain and in the form of extended business collaboration) can be difficult to maintain, and stakeholder analysis is important in defining the company's strategic position in a network of business (Trienekens \& Beulens, 2001). The use of coercive power creates a relationship based on compliance rather than collaboration, which indicates the need for research to specifically target instances of coercive power in strategic alliances, to identify their impact on inter-organizational relationships (Byrne \& Power, 2014). Clearly, the extensions of stakeholder concerns to the context of the inter-organizational supply chain still need to be researched (Juttner et al., 2020).

On the other hand, the effectiveness of new organizational forms, such as the establishment of sustainability development teams with regional business unit managers and selected suppliers, can be investigated (Juttner et al., 2020). Policy makers can support the development of sustainability incentives in dyadic relationships, assisting cooperation, shippers and logistics service providers and creating awareness of end consumer sustainability (Kudla \& Klaas-Wissing, 2012). Therefore, in transport supply chains, it is important to point out that there are not only drivers but also small self-employed workers, who can be added as agents and make the relationships between the chains even more complex. Changing roles - an agent becoming a principal - would be highly relevant for further study, especially in a longitudinal manner (Forslund et al., 2021).

With regard to the third sector, it is still necessary to understand whether the involvement of NGOs has an impact on the development of trust and commitment in relationships
Supply chain management 
REGE 29,2

upstream of the supply chain (Wilhelm et al., 2016). Risk and gain sharing mechanisms imply a new culture for buyers, previously used only to push risk to suppliers (Norrman, 2008). Beyond monitoring practices in service triads, addressing the effectiveness and outcome of the mechanism, further investigations are expected to identify which procurement approach in service triads leads to the best-acquired quality, relevant to service buyers, to increase understanding of the service triads (Uenk \& Telgen, 2019).

Finally, a challenge both for the alignment of supply chain incentives and for the congruence of internal goals is external and internal integration and the impact of incentives (Norrman \& Naslund, 2019). The integration of agency theory with other organizational theories, such as TCE and relational exchange, offers the promise of potentially compensating for its limitations (Fayezi et al., 2012). To explain why some buyer-supplier relationships are effective in promoting better performance at various levels, the stewardship theory may be more appropriate (Aßländer et al., 2016). Given the complexity of supply chain relationships, investigation of industry-specific chains can increase the conceptual discussion (Fayezi et al., 2012). Equally, to what extent the services provided act in an opportunistic way due to the management instruments (monitoring) applied (Uenk \& Telgen, 2019).

This research has, therefore, multiple implications. First, a state-of-the-art synthesis of the agency theory literature in supply chain management is offered. Analyzes were also performed to understand the results found through descriptive analysis, cocitation network, word cloud and discussion of the main themes. Finally, an extensive agenda for future research, based on gaps or incipient problems, was presented. Second, the research supports that agency theory has more than necessary application when it comes to supply chain management. Either through the mediation of the chain's relationships or as a protector of the principal's interests before the agent, whether in dyads or triads, in manufacturing, or services. Although the absence in some areas and incipience in others is evident, the use of agency theory to study the management of the supply chain is the main argument of the research, and it serves as an incentive and starting point for future studies.

\section{References}

Aßländer, M. S., Roloff, J., \& Nayır, D. Z. (2016). Suppliers as Stewards? Managing social standards in first- and second-tier suppliers. Journal of Business Ethics, 139(4), 661-683. doi: 10.1007/s10551016-3148-0.

Azmi, F. R., Musa, H., Chew, B. C., \& Jagiripu, I. P. (2021). Supply risk management: A case study of halal food industry in Malaysia. Uncertain Supply Chain Management, 9(2), 501-512. doi: 10. 5267/j.uscm.2021.1.001.

Botelho, L. L. R., Cunha, C. C. A., \& Macedo, M. (2011). O Método da Revisão Integrativa nos Estudos Organizacionais. Gestão e Sociedade, 5(11), 121-136. doi: 10.1017/CBO9781107415324.004.

Byrne, R., \& Power, D. (2014). Exploring agency, knowledge and power in an Australian bulk cereal supply chain: A case study. Supply Chain Management, 19(4), 431-444. doi: 10.1108/SCM-082013-0297.

Choi, T. Y., \& Liker, J. K. (1995). Bringing Japanese continuous improvement approaches to U.S. Manufacturing: The roles of process orientation and communications. Decision Sciences, 26(5), 589-620. doi: 10.1111/j.1540-5915.1995.tb01442.x.

Ciliberti, F., De Haan, J., De Groot, G., \& Pontrandolfo, P. (2011). CSR codes and the principal-agent problem in supply chains: Four case studies. Journal of Cleaner Production, 19(8), 885-894. doi: 10.1016/j.jclepro.2010.09.005.

Cole, R., \& Aitken, J. (2019). Selecting suppliers for socially sustainable supply chain management: post-exchange supplier development activities as pre-selection requirements. Production Planning and Control, 30(14), 1184-1202. doi: 10.1080/09537287.2019.1595208. 
Cragg, T., \& McNamara, T. (2018). An ICT-based framework to improve global supply chain integration for final assembly SMES. Journal of Enterprise Information Management, 31(5), 634-657. doi: 10.1108/JEIM-04-2014-0038.

Eisenhardt, K. M. (1989). Agency theory: an assessment and review. Academy of Management Review, 14(1), $57-74$.

Ekanayake, S. (2004). Agency theory, national culture and management control systems. The Journal of American Academy of Business Cambridge, 4(1/2), 49-54.

Ellram, L. M., Tate, W. L., \& Choi, T. Y. (2020). The conflicted role of purchasing in new product development costing. Journal of Supply Chain Management, 56(1), 3-32. doi: 10.1111/jscm.12217.

Fayezi, S., O'Loughlin, A., \& Zutshi, A. (2012). Agency theory and supply chain management: A structured literature review. Supply Chain Management, 17(5), 556-570. doi: 10.1108/ 13598541211258618.

Fitri, H., Elmanizar,Nugraha, A. T., Yakub, A., \& Cahyono, B. P. (2019). The application of agency theory in supply chain finance: A case of Indonesian manufacturing firms. International Journal of Supply Chain Management, 8(3), 23-32.

Forslund, H., Björklund, M., \& Ülgen, V. S. (2021). Challenges in extending sustainability across a transport supply chain. Supply Chain Management, (February). doi: 10.1108/SCM-06-2020-0285.

Gligor, D., Bozkurt, S., Russo, I., \& Omar, A. (2019). A look into the past and future: Theories within supply chain management, marketing and management. Supply Chain Management, 24(1), 170 186. doi: 10.1108/SCM-03-2018-0124.

Gong, M., Gao, Y., Koh, L., Sutcliffe, C., \& Cullen, J. (2019). The role of customer awareness in promoting firm sustainability and sustainable supply chain management. International Journal of Production Economics, 217(January), 88-96. doi: 10.1016/j.ijpe.2019.01.033.

Handley, S. M., \& Gray, J. V. (2013). Inter-organizational quality management: The use of contractual incentives and monitoring mechanisms with outsourced manufacturing. Production and Operations Management, 22(6), 1540-1556. doi: 10.1111/j.1937-5956.2012.01351.x.

Heaslip, G., \& Kovács, G. (2019). Examination of service triads in humanitarian logistics. International Journal of Logistics Management, 30(2), 595-619. doi: 10.1108/IJLM-09-2017-0221.

Heide, J. B., Wathne, K. H., \& Rokkan, A. I. (2007). Interfirm monitoring, social contracts, and relationship outcomes. Journal of Marketing Research, 44(3), 425-433. doi: 10.1509/jmkr.44. 3.425 .

Juttner, U., Windler, K., Podleisek, A., Gander, M., \& Meldau, S. (2020). Implementing supplier management strategies for supply chain sustainability risks in multinational companies. TQM Journal. doi: 10.1108/TQM-05-2019-0136.

Kros, J. F., \& Nadler, S. S. (2010). The impact of Sarbanes-Oxley on off-balance sheet. Journal of Business, 31(1), 63-78.

Kudla, N. L., \& Klaas-Wissing, T. (2012). Sustainability in shipper-logistics service provider relationships: A tentative taxonomy based on agency theory and stimulus-response analysis. Journal of Purchasing and Supply Management, 18(4), 218-231. doi: 10.1016/j.pursup.2012. 04.001 .

Lechler, S., Canzaniello, A., \& Hartmann, E. (2019). Assessment sharing intra-industry strategic alliances: Effects on sustainable supplier management within multi-tier supply chains. International Journal of Production Economics, 217(November), 64-77. doi: 10.1016/j.ijpe.2019. 01.005 .

Li, G., Fan, H., Lee, P. K. C., \& Cheng, T. C. E. (2015). Joint supply chain risk management: An agency and collaboration perspective. International Journal of Production Economics, 164, 83-94. doi: 10.1016/j.ijpe.2015.02.021.

Liu, J., Feng, Y., Zhu, Q., \& Sarkis, J. (2018). Green supply chain management and the circular economy: Reviewing theory for advancement of both fields. International Journal of Physical Distribution and Logistics Management, 48(8), 794-817. doi: 10.1108/IJPDLM-01-2017-0049. 
REGE 29,2

Massimino, B., \& Lawrence, B. (2019). Supersize me? Franchisee size and voluntary compliance with corporate brand-building initiatives. Journal of Operations Management, 65(7), 659-684. doi: 10. 1002/joom.1056.

Miller, J. W. (2017). A multivariate time-Series examination of motor carrier safety behaviors. Journal of Business Logistics, 38(4), 266-289. doi: 10.1111/jbl.12162.

Miller, J. W., Saldanha, J. P., Hunt, C. S., \& Mello, J. E. (2013). Combining formal controls to improve firm performance. Journal of Business Logistics, 34(4), 301-318. doi: 10.1111/jbl.12028.

Miller, J. W., Bolumole, Y., \& Schwieterman, M. A. (2020). Electronic logging device compliance of small and medium size motor carriers prior to the December 18, 2017, mandate. Journal of Business Logistics, 41(1), 67-85. doi: 10.1111/jbl.12207.

Morgan, N. A., Kaleka, A., \& Gooner, R. A. (2007). Focal supplier opportunism in supermarket retailer category management. Journal of Operations Management, 25(2), 512-527. doi: 10.1016/j.jom. 2006.05.006.

Norrman, A. (2008). Supply chain risk-sharing contracts from a buyers' perspective: Content and experiences. International Journal of Procurement Management, 1(4), 371-393. doi: 10.1504/ IJPM.2008.018426.

Norrman, A., \& Naslund, D. (2019). Supply chain incentive alignment: The gap between perceived importance and actual practice. Operations and Supply Chain Management, 12(3), 129-142. doi: 10.31387/oscm0380237.

Rungtusanatham, M., Rabinovich, E., Ashenbaum, B., \& Wallin, C. (2007). Vendor-owned inventory management arrangements in retail: An agency theory perspective. Journal of Business, 28(1), 111-136.

Sayed, M., Hendry, L. C., \& Zorzini Bell, M. (2020). Sustainable procurement: Comparing in-house and outsourcing implementation modes. Production Planning and Control. doi: 10.1080/09537287. 2020.1717661.

Selviaridis, K., \& Norrman, A. (2014). Performance-based contracting in service supply chains: A service provider risk perspective. Supply Chain Management, 19(2), 153-172. doi: 10.1108/SCM06-2013-0216.

Shafiq, A., Johnson, P. F., Klassen, R. D., \& Awaysheh, A. (2017). Exploring the implications of supply risk on sustainability performance. International Journal of Operations and Production Management, 37(10), 1386-1407. doi: 10.1108/IJOPM-01-2016-0029.

Shapiro, S. P. (2005). Agency theory. Annual Review of Sociology, 31, 263-284. doi: 10.1146/annurev. soc.31.041304.122159.

Tate, W. L., Ellram, L. M., Bals, L., Hartmann, E., \& van der Valk, W. (2010). An Agency Theory perspective on the purchase of marketing services. Industrial Marketing Management, 39(5), 806-819. doi: 10.1016/j.indmarman.2009.08.005.

Trienekens, J. H., \& Beulens, A. J. M. (2001). Views on inter-enterprise relationships. Production Planning and Control, 12(5), 466-477. doi: 10.1080/09537280110042693.

Tse, Y. K., Zhang, M., \& Jia, F. (2018). The effects of risk and reward sharing on quality performance. International Journal of Operations and Production Management, 38(12), 2367-2388. doi: 10. 1108/IJOPM-12-2016-0759.

Uenk, N., \& Telgen, J. (2019). Managing challenges in social care service triads - exploring public procurement practices of Dutch municipalities. Journal of Purchasing and Supply Management, 25(1), 5-17. doi: 10.1016/j.pursup.2018.08.001.

van der Krift, H. J. C., van Weele, A. J., \& Gevers, J. M. P. (2021). Developing a perceptual distance monitor for client-contractor collaborations. Supply Chain Management, 26(1), 48-64. doi: 10. 1108/SCM-12-2019-0432.

Van der Valk, W., \& Van Iwaarden, J. (2011). Monitoring in service triads consisting of buyers, subcontractors and end customers. Journal of Purchasing and Supply Management, 17(3), 198206. doi: 10.1016/j.pursup.2011.05.002. 
Vlachos, I., \& Dyra, S. C. (2020). Theorizing coordination, collaboration and integration in multisourcing triads (B3B triads). Supply Chain Management, 25(3), 285-300. doi: 10.1108/SCM-012019-0006.

Wallace, D. W., Johnson, J. L., \& Umesh, U. N. (2009). Multichannels strategy implementation: The role of channel alignment capabilities. Decision Sciences, 40(4), 869-900. doi: 10.1111/j.1540-5915. 2009.00254.x.

Wandfluh, M., Hofmann, E., \& Schoensleben, P. (2016). Financing buyer-supplier dyads: an empirical analysis on financial collaboration in the supply chain. International Journal of Logistics Research and Applications, 19(3), 200-217. doi: 10.1080/13675567.2015.1065803.

Whittemore, R., \& Knafl, K. (2005). The integrative review: Updated methodology. Journal of Advanced Nursing, 52(5), 546-553. doi: 10.1111/j.1365-2648.2005.03621.x.

Wiese, A., \& Toporowski, W. (2013). CSR failures in food supply chains - an agency perspective. British Food Journal, 115(1), 92-107. doi: 10.1108/00070701311289894.

Wilhelm, M. M., Blome, C., Bhakoo, V., \& Paulraj, A. (2016). Sustainability in multi-tier supply chains: Understanding the double agency role of the first-tier supplier. Journal of Operations Management, 41, 42-60. doi: 10.1016/j.jom.2015.11.001.

Zhang, J. J., Lawrence, B., \& Anderson, C. K. (2015). An agency perspective on service triads: Linking operational and financial performance. Journal of Operations Management, 35, 56-66. doi: 10. 1016/j.jom.2014.10.005.

Zsidisin, G. A., Ellram, L. M., Carter, J. R., \& Cavinato, J. L. (2004). An analysis of supply risk assessment techniques. International Journal of Physical Distribution and Logistics Management, 34(5), 397-413. doi: 10.1108/09600030410545445.

$\mathrm{Zu}, \mathrm{X}$., \& Kaynak, H. (2012). An agency theory perspective on supply chain quality management. International Journal of Operations and Production Management, 32(4), 423-446. doi: 10.1108/ 01443571211223086.
Supply chain management

195 
REGE

29,2

\section{Appendix}

Articles selected for analysis

Agustina, I. L., Fauziv, E., Anwar, A., Ogalo, H. S., \& Ratnasari, I. (2019). The role of financial management in bringing efficiency in supply chain management. International Journal of Supply Chain Management, 8(3), 1-9

Aigbogun, O., Ghazali, Z., \& Razali, R. (2016). The mediating impact of halal logistics on supply chain resilience: An agency perspective. International Review of Management and Marketing, 6(4), 209-216

Aßländer, M. S., Roloff, J., \& Nayır, D. Z. (2016). Suppliers as Stewards? Managing social standards in first- and second-tier suppliers. Journal of Business Ethics, 139(4), 661-683. https://doi.org/10.1007/s10551-016-3148-0

Azmi, F. R., Musa, H., Chew, B. C., \& Jagiripu, I. P. (2021). Supply risk management: A case study of halal food industry in Malaysia. Uncertain Supply Chain Management, 9(2), 501-512. https://doi.org/10.5267/j.uscm.2021.1.001

Brahmana, S., Hendar, Mu'minah, I., \& Razimi, M. S. B. A. (2019). Supply chain governance, corporate governance and supply chain capabilities: An unexplored nexus. International Journal of Supply Chain Management, 8(2), 134-141

Byrne, R., \& Power, D. (2014). Exploring agency, knowledge and power in an Australian bulk cereal supply chain: A case study. Supply Chain Management, 19(4), 431-444. https://doi.org/10.1108/SCM-08-2013-0297

Cheng, S. K., \& Kam, B. H. (2008). A conceptual framework for analysing risk in supply networks. Journal of Enterprise Information Management, 21(4), 345-360. https://doi.org/10.1108/17410390810888642

Ciliberti, F., De Haan, J., De Groot, G., \& Pontrandolfo, P. (2011). CSR codes and the principal-agent problem in supply chains: Four case studies. Journal of Cleaner Production, 19(8), 885-894. https://doi.org/10.1016/j.jclepro.2010.09.005

Cole, R., \& Aitken, J. (2019). Selecting suppliers for socially sustainable supply chain management: Post-exchange supplier development activities as pre-selection requirements. Production Planning and Control, 30(14), 1184-1202. https://doi.org/10. 1080/09537287.2019.1595208

Cragg, T., \& McNamara, T. (2018). An ICT-based framework to improve global supply chain integration for final assembly SMES. Journal of Enterprise Information Management, 31(5), 634-657. https://doi.org/10.1108/JEIM-04-2014-0038 Dekkers, R., de Boer, R., Gelsomino, L. M., de Goeij, C., Steeman, M., Zhou, Q., . . Souter, V. (2020). Evaluating theoretical conceptualisations for supply chain and finance integration: A Scottish focus group. International Journal of Production Economics, 220(July 2019), 107451. https://doi.org/10.1016/j.ijpe.2019.07.024

Dubey, R., Gunasekaran, A., Childe, S. J., \& Papadopoulos, T. (2018). Skills needed in supply chain-human agency and social capital analysis in third party logistics. Management Decision, 56(1), 143-159. https://doi.org/10.1108/MD-04-2017-0428

Dupuis, M., \& Tissier-Desbordes, E. (1996). Trade marketing and retailing: A European approach. Journal of Retailing and Consumer Services, 3(1), 43-51. https://doi.org/10.1016/0969-6989(95)00045-3

Ellram, L. M., Tate, W. L., \& Choi, T. Y. (2020). The Conflicted role of Purchasing in new Product Development Costing. Journal of Supply Chain Management, 56(1), 3-32. https://doi.org/10.1111/jscm.12217

Fayezi, S., O'Loughlin, A., \& Zutshi, A. (2012). Agency theory and supply chain management: A structured literature review. Supply Chain Management, 17(5), 556-570. https://doi.org/10.1108/13598541211258618

Fitri, H., Elmanizar, Nugraha, A. T., Yakub, A., \& Cahyono, B. P. (2019). The application of agency theory in supply chain finance: A case of Indonesian manufacturing firms. International Journal of Supply Chain Management, 8(3), 23-32

Forslund, H., Björklund, M., \& Svensson Ülgen, V. (2021). Challenges in extending sustainability across a transport supply chain. Supply Chain Management, (february). https://doi.org/10.1108/SCM-06-2020-0285

Gong, M., Gao, Y., Koh, L., Sutcliffe, C., \& Cullen, J. (2019). The role of customer awareness in promoting firm sustainability and sustainable supply chain management. International Journal of Production Economics, 217(January), 88-96. https://doi.org/10. 1016/j.jpe.2019.01.033

Halldórsson, Á., \& Skjøtt-Larsen, T. (2006). Dynamics of relationship governance in TPL arrangements - a dyadic perspective. International Journal of Physical Distribution \& Logistics Management, 36(7), 490-506. https://doi.org/10.1108/ 09600030610684944

Handley, S. M., \& Gray, J. V. (2013). Inter-organizational quality management: The use of contractual incentives and monitoring mechanisms with outsourced manufacturing. Production and Operations Management, 22(6), 1540-1556. https:// doi.org/10.1111/j.1937-5956.2012.01351.x

Heaslip, G., \& Kovács, G. (2019). Examination of service triads in humanitarian logistics. International Journal of Logistics Management, 30(2), 595-619. https://doi.org/10.1108/IJLM-09-2017-0221

Hsuan, J., \& Parisi, C. (2020). Mapping the supply chain of ship recycling. Marine Policy, 118(August 2019), 103979. https://doi. org/10.1016/j.marpol.2020.103979

Juttner, U., Windler, K., Podleisek, A., Gander, M., \& Meldau, S. (2020). Implementing supplier management strategies for supply chain sustainability risks in multinational companies. TQM Journal, Ahead of print(Ahead of print). https://doi.org/10. 1108/TQM-05-2019-0136

Kros, J.F., Nadler, S. S. (2010). The impact of Sarbanes-Oxley on off-balance sheet supply chain activities. Journal of Business, 31(1), 63-78

Kudla, N. L., \& Klaas-Wissing, T. (2012). Sustainability in shipper-logistics service provider relationships: A tentative taxonomy based on agency theory and stimulus-response analysis. Journal of Purchasing and Supply Management, 18(4), 218231. https://doi.org/10.1016/j.pursup.2012.04.001

(continued) 
Articles selected for analysis

Lechler, S., Canzaniello, A., \& Hartmann, E. (2019). Assessment sharing intra-industry strategic alliances: Effects on sustainable supplier management within multi-tier supply chains. International Journal of Production Economics, 217(November 2018), 64-77. https://doi.org/10.1016/j.ijpe.2019.01.005

Li, G., Fan, H., Lee, P. K. C., \& Cheng, T. C. E. (2015). Joint supply chain risk management: An agency and collaboration perspective. International Journal of Production Economics, 164, 83-94. https://doi.org/10.1016/j.ijpe.2015.02.021

Liu, J., Feng, Y., Zhu, Q., \& Sarkis, J. (2018). Green supply chain management and the circular economy: Reviewing theory for advancement of both fields. International Journal of Physical Distribution and Logistics Management, 48(8), 794-817. https:// doi.org/10.1108/IJPDLM-01-2017-0049

Massimino, B., \& Lawrence, B. (2019). Supersize me? Franchisee size and voluntary compliance with corporate brand-building initiatives. Journal of Operations Management, 65(7), 659-684. https://doi.org/10.1002/joom.1056

Miller, J. W. (2017). A Multivariate time-Series examination of Motor carrier safety behaviors. Journal of Business Logistics, 38(4), 266-289. https://doi.org/10.1111/jbl.12162

Miller, J. W., Bolumole, Y., \& Schwieterman, M. A. (2020). Electronic Logging Device compliance of small and medium size Motor carriers Prior to the December 18, 2017, mandate. Journal of Business Logistics, 41(1), 67-85. https://doi.org/10.1111/jbl. 12207

Miller, J. W., Saldanha, J.P., Hunt, C. S., \& Mello, J.E. (2013). Combining formal controls to improve firm performance.Journal of Business Logistics, 34(4), 301-318. https://doi.org/10.1111/jbl.12028

Morgan, N. A., Kaleka, A., \& Gooner, R. A. (2007). Focal supplier opportunism in supermarket retailer category management. Journal of Operations Management, 25(2), 512-527. https://doi.org/10.1016/j.jom.2006.05.006

Norrman, A. (2008). Supply chain risk-sharing contracts from a buyers' perspective: Content and experiences. International Journal of Procurement Management, 1(4), 371-393. https://doi.org/10.1504/IJPM.2008.018426

Norrman, A., \& Naslund, D. (2019). Supply chain incentive alignment: The gap between perceived importance and actual practice. Operations and Supply Chain Management, 12(3), 129-142. https://doi.org/10.31387/oscm0380237

Prawira, A., Syafdinal, Anwar, A., \& Alaeddin, O. (2019). Operational performance of an agile supply chain: A cash to cash approach. International Journal of Supply Chain Management, 8(2), 594-602

Rungtusanatham, M., Rabinovich, E., Ashenbaum, B., \& Wallin, C. (2007). Vendor-owned inventory management arrangements in retail: An agency theory perspective. Journal of Business, 28(1), 111-136

Saudi, M. H. M., Supriadi, H., Sunjana, \& Razimi, M. S. A. (2019). Supply chain governance, corporate governance and firm supply performance: A paradox of prediction. International Journal of Supply Chain Management, 8(2), 105-113

Sayed, M., Hendry, L. C., \& Zorzini Bell, M. (2020). Sustainable procurement: Comparing in-house and outsourcing implementation modes. Production Planning and Control, Ahead of print(Ahead of print). https://doi.org/10.1080/09537287. 2020.1717661

Scott, A., Balthrop, A., \& Miller, J. W. (2020). Unintended responses to IT-enabled monitoring: The case of the electronic logging device mandate. Journal of Operations Management, Early View. https://doi.org/10.1002/joom.1110

Selviaridis, K., \& Norrman, A. (2014). Performance-based contracting in service supply chains: A service provider risk perspective. Supply Chain Management, 19(2), 153-172. https://doi.org/10.1108/SCM-06-2013-0216

Shafiq, A., Johnson, P. F., Klassen, R. D., \& Awaysheh, A. (2017). Exploring the implications of supply risk on sustainability performance. International Journal of Operations and Production Management, 37(10), 1386-1407. https://doi.org/10.1108/ IJOPM-01-2016-0029

Shevchenko, A., Pagell, M., Lévesque, M., \& Johnston, D. (2020). Preventing supplier non-conformance: Extending the agency theory perspective. International Journal of Operations and Production Management, 40(3), 315-340. https://doi.org/10.1108/ IJOPM-08-2019-0601

Smith, A. D. (2010). The subprime mortgage crisis and the possible effects on supplier integration strategies. International Journal of Services and Operations Management, 6(1), 38-56. https://doi.org/10.1504/IJSOM.2010.029489

Trienekens, J. H., \& Beulens, A. J. M. (2001). Views on inter-enterprise relationships. Production Planning and Control, 12(5), 466-477. https://doi.org/10.1080/09537280110042693

Tse, Y. K., Zhang, M., \& Jia, F. (2018). The effects of risk and reward sharing on quality performance. International Journal of Operations and Production Management, 38(12), 2367-2388. https://doi.org/10.1108/IJOPM-12-2016-0759

Uenk, N., \& Telgen, J. (2019). Managing challenges in social care service triads - Exploring public procurement practices of Dutch municipalities. Journal of Purchasing and Supply Management, 25(1), 5-17. https://doi.org/10.1016/j.pursup.2018.08.001 van der Krift, H. J. C., van Weele, A. J., \& Gevers, J. M. P. (2021). Developing a perceptual distance monitor for client-contractor collaborations. Supply Chain Management, 26(1), 48-64. https://doi.org/10.1108/SCM-12-2019-0432

Vlachos, I., \& Dyra, S. C. (2020). Theorizing coordination, collaboration and integration in multi-sourcing triads (B3B triads). Supply Chain Management, 25(3), 285-300. https://doi.org/10.1108/SCM-01-2019-0006

Wallace, D. W., Johnson, J. L., \& Umesh, U. N. (2009). Multichannels strategy implementation: The role of channel alignment capabilities. Decision Sciences, 40(4), 869-900. https://doi.org/10.1111/j.1540-5915.2009.00254.x

Wandfluh, M., Hofmann, E., \& Schoensleben, P. (2016). Financing buyer-supplier dyads: an empirical analysis on financial collaboration in the supply chain. International Journal of Logistics Research and Applications, 19(3), 200-217. https://doi.org/ 10.1080/13675567.2015.1065803

(continued) 
REGE

29,2

198
Articles selected for analysis

Wiese, A., \& Toporowski, W. (2013). CSR failures in food supply chains - an agency perspective. British Food Journal, 115(1), 92-107. https://doi.org/10.1108/00070701311289894

Wilhelm, M. M., Blome, C., Bhakoo, V., \& Paulraj, A. (2016). Sustainability in multi-tier supply chains: Understanding the double agency role of the first-tier supplier. Journal of Operations Management, 41, 42-60. https://doi.org/10.1016/j.jom.2015. 11.001

Wong, W. P., Soh, K. L., Sinnandavar, C. M., \& Mushtaq, N. (2018). Could the service consumption-production interface lift national logistics performance? Resources, Conservation and Recycling, 128, 222-239. https://doi.org/10.1016/j.resconrec.2016. 10.002

Zsidisin, G. A., Ellram, L. M., Carter, J. R., \& Cavinato, J. L. (2004). An analysis of supply risk assessment techniques. International Journal of Physical Distribution and Logistics Management, 34(5), 397-413. https://doi.org/10.1108/ 09600030410545445

$\mathrm{Zu}, \mathrm{X}$., \& Kaynak, H. (2012). An agency theory perspective on supply chain quality management. International Journal of Operations and Production Management, 32(4), 423-446. https://doi.org/10.1108/01443571211223086

\section{Corresponding author}

Raul Beal Partyka can be contacted at: raul.partyka@fgv.edu.br

Associate Editor: Ana Lucia Figueiredo Facin

For instructions on how to order reprints of this article, please visit our website: 